\title{
Multi-decadal uptake of carbon dioxide into subtropical mode water of the North Atlantic Ocean
}

\author{
N. R. Bates \\ Bermuda Institute of Ocean Sciences, Ferry Reach, Bermuda \\ Correspondence to: N. R. Bates (nick.bates@bios.edu) \\ Received: 28 November 2011 - Published in Biogeosciences Discuss.: 21 December 2011 \\ Revised: 1 June 2012 - Accepted: 11 June 2012 - Published: 18 July 2012
}

\begin{abstract}
Natural climate variability impacts the multidecadal uptake of anthropogenic carbon dioxide $\left(C_{\text {ant }}\right)$ into the North Atlantic Ocean subpolar and subtropical gyres. Previous studies have shown that there is significant uptake of $\mathrm{CO}_{2}$ into subtropical mode water (STMW) of the North Atlantic. STMW forms south of the Gulf Stream in winter and constitutes the dominant upper-ocean water mass in the subtropical gyre of the North Atlantic Ocean. Observations at the Bermuda Atlantic Time-series Study (BATS) site near Bermuda show an increase in dissolved inorganic carbon (DIC) of $+1.51 \pm 0.08 \mu \mathrm{mol} \mathrm{kg}^{-1} \mathrm{yr}^{-1}$ between 1988 and 2011, but also an increase in ocean acidification indicators such as $\mathrm{pH}$ at rates $\left(-0.0022 \pm 0.0002 \mathrm{yr}^{-1}\right)$ higher than the surface ocean (Bates et al., 2012). It is estimated that the sink of $\mathrm{CO}_{2}$ into STMW was $0.985 \pm 0.018 \mathrm{PgC}\left(\mathrm{Pg}=10^{15}\right.$ g C) between 1988 and 2011 (70 $\pm 1.8 \%$ of which is due to uptake of $C_{\text {ant }}$ ). The sink of $\mathrm{CO}_{2}$ into the STMW is $20 \%$ of the $\mathrm{CO}_{2}$ uptake in the North Atlantic Ocean between $14^{\circ}-$ $50^{\circ} \mathrm{N}$ (Takahashi et al., 2009). However, the STMW sink of $\mathrm{CO}_{2}$ was strongly coupled to the North Atlantic Oscillation (NAO), with large uptake of $\mathrm{CO}_{2}$ into STMW during the 1990s during a predominantly NAO positive phase. In contrast, uptake of $\mathrm{CO}_{2}$ into STMW was much reduced in the 2000s during the NAO neutral/negative phase. Thus, NAO induced variability of the STMW $\mathrm{CO}_{2}$ sink is important when evaluating multi-decadal changes in North Atlantic Ocean $\mathrm{CO}_{2}$ sinks.
\end{abstract}

\section{Introduction}

The North Atlantic Ocean contributes approximately $25 \%$ to the global ocean sink of anthropogenic carbon dioxide $\left(\mathrm{CO}_{2}\right)$ from the atmosphere (Takahashi et al., 2002, 2009). Recent studies have suggested that the basinwide $\mathrm{CO}_{2}$ sink in the North Atlantic has decreased over the last decade (Schuster and Watson, 2007; Watson et al., 2009). However, ocean observations conducted over longer timescales indicate that surface ocean $p \mathrm{CO}_{2}$ (partial pressure of $\mathrm{CO}_{2}$ ) has increased at the same rate as the atmosphere, with the implication that the North Atlantic Ocean $\mathrm{CO}_{2}$ sink has not changed significantly over multi-decadal timescales (McKinley et al., 2004; Thomas et al., 2008; McKinley et al., 2011; Bates et al., 2012). Complicating any assessment of change in the $\mathrm{CO}_{2}$ sink-source strength of the North Atlantic Ocean is a recognition that natural interannual variability imparted by modes of climate variability - such as the North Atlantic Oscillation (NAO; Hurrell and Deser, 2009), Atlantic Multidecadal Variability (AMV; McKinley et al., 2004; Ullman et al., 2009; Metzl et al., 2010; McKinley et al., 2011) and El Niño-Southern Oscillation (ENSO) - play important roles in controlling air-sea $\mathrm{CO}_{2}$ fluxes in the subtropical and subpolar gyres of the basin (Gruber et al., 2002; Bates et al., 2002; Thomas et al., 2008; Gruber, 2009; Levine et al., 2011).

In the subtropical gyre of the North Atlantic Ocean, the formation of subtropical mode water (STMW) or Eighteen Degree Water (EDW; Worthington, 1959, 1976; Hanawa and Talley, 2001) in winter just south of the Gulf Stream (Marshall et al., 2009; Fig. 1a) may contribute substantively to variability in the $\mathrm{CO}_{2}$ sink in the North Atlantic (Gruber et al., 2002; Bates et al., 2002; Gruber, 2009). These studies indicate that the STMW absorbed 0.030 to $0.240 \mathrm{Pg} \mathrm{C} \mathrm{yr}^{-1}$ in the 1990s (Gruber et al., 2002; Bates et al., 2002), while model studies suggest that the wintertime replenishment of $\mathrm{CO}_{2}$ to the storage of anthropogenic $\mathrm{CO}_{2}$ in STMW varies by approximately $0.100 \mathrm{Pg} \mathrm{Cyr}^{-1}$, depending on the state of the NAO (Levine et al., 2011). More recently, studies have focussed on determining the rate of $\mathrm{CO}_{2}$ uptake at 


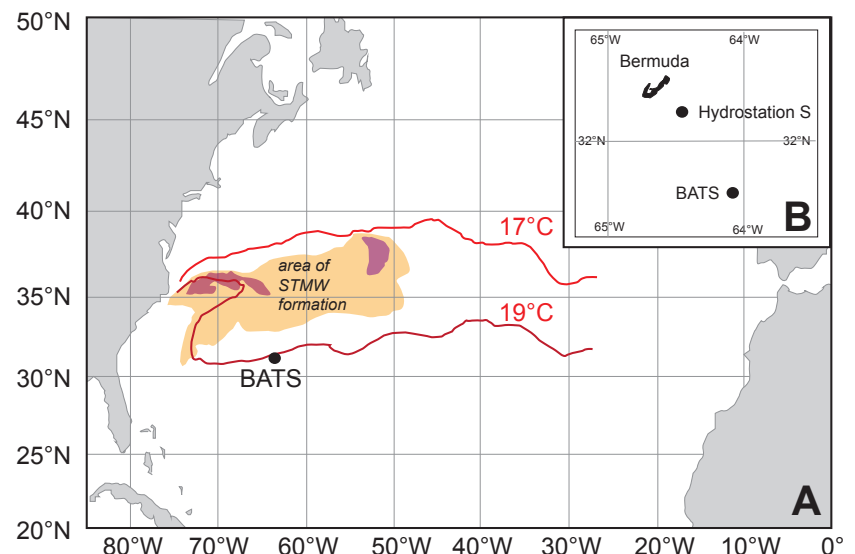

Fig. 1. Location map of general area of STMW outctop and the BATS site near Bermuda in the NW Atlantic Ocean. (A) General outcrop area of STMW in the NW Atlantic Ocean, showing locations of climatological $17^{\circ} \mathrm{C}$ and $19^{\circ} \mathrm{C}$ isotherms and mean STMW formation rate area (orange and purple) for the 2004-2006 period from Marshall et al. (2009). This figure is modified from Fig. 2a and Fig. 12a of Marshall et al. (2009). (B) Location of the BATS (Bermuda Atlantic Time-series Study; $31^{\circ} 40^{\prime} \mathrm{N}, 64^{\circ} 10^{\prime} \mathrm{W}$ ) site as well as the long-term Hydrostation $\mathrm{S}$ ocean time-series.

the site of STMW outcrop during its winter formation (Andersson et al., 2012) as part of the CLIMODE (Climate of Mode Water) project (Marshall et al., 2009). In this paper, multi-decadal changes from 1988 to 2011 in the dissolved inorganic carbon (DIC) content of the STMW observed at the Bermuda Atlantic Time-series Study (BATS; $31^{\circ} 40^{\prime} \mathrm{N}$, $64^{\circ} 10^{\prime} \mathrm{W}$; Fig. 1b) site near Bermuda are evaluated. Estimates of how much $\mathrm{CO}_{2}$ has been taken up in STMW over the last 2 decades are made. This is viewed in context with rate of equilibration of the ocean with anthropogenic $\mathrm{CO}_{2}$ increase in the atmosphere, observed increases in the rates of phytoplankton primary production, and vertical export of sinking organic carbon in the North Atlantic sub-tropical gyre (Lomas et al., 2010). Finally, relationships between the DIC content of STMW and NAO state are examined to determine whether the uptake and storage of $\mathrm{CO}_{2}$ in STMW has changed contemporaneously with the NAO.

STMW forms during winter just south of the Gulf Stream in a region of very high heat loss from the ocean, which triggers intense convective mixing (Marshall et al., 2009) and subsequent isopycnal transfer into the thermocline of the subtropical gyre. STMW is a classically identified water mass that has a temperature and salinity range of $17.8-18.4{ }^{\circ} \mathrm{C}$ and $36.5 \pm 0.05$, respectively, and is commonly identified by a characteristic minimum in the vertical gradient of potential density or potential isopycnic vorticity (Jenkins, 1982). The volume of STMW formed each winter ranges from about 4.6 to 8 Svy (where $1 \mathrm{Svy}=3.15 \times 10^{13} \mathrm{~m}^{3}$ and corresponds to a $1 \mathrm{~Sv}\left(10^{6} \mathrm{~m}^{3} \mathrm{~s}^{-1}\right)$ flow sustained for $1 \mathrm{yr}$; Speer and Tziperman, 1992; Kwon and Riser, 2004; Maze et al., 2009;
Forget et al., 2011). The volume of STMW in the subtropical gyre is approximately 75 to 80 Svy (Worthington, 1976; Forget et al., 2011) with seasonal and annual fluctuations ranging from 3.5 to $8.6 \mathrm{Svy}$ (Kwon and Riser, 2004; Forget et al., 2011) and annual fluctuations at $1.4 \mathrm{Svy}$, respectively. The latter rate implies that the residence time of STMW is $50 \mathrm{yr}$, but recent studies indicate that approximately $8 \mathrm{yr}$ is sufficient to ventilate STMW (Forget et al., 2011).

The outcrop and volume of STMW formation is coupled to the NAO, which is the dominant climate mode that influences interannual and multi-decadal variability in the North Atlantic Ocean (Hurrell and Deser, 2009; Jenkins, 1982; Hurrell, 1995). During NAO positive phases, stronger atmospheric pressure gradients between the subpolar and subtropical region increase winter storm frequency and shift the Gulf Stream northward (Hurrell, 1995; Hurrell et al., 2001; Marshall et al., 2001) with a lag of about 1 to 2 yr. During NAO negative phases, the Icelandic atmospheric low pressure shifts winter storm tracks southward, winter storms tend to be fewer in number, and the Gulf Stream shifts southward. The outcrop area, extent and formation rate of STMW south of the Gulf Stream also shift in concert with NAO variability (Alfutis and Cornillon, 2001; Joyce et al., 2000; Levine et al., 2011).

\section{Methods and materials}

\subsection{Determining long-term trends}

A time-series of observations of seawater carbonate chemistry in the upper ocean have been collected in the subtropical gyre of the North Atlantic Ocean near Bermuda since 1988 at the Bermuda Atlantic Time-series Study (BATS) site (Bates, 2007; Bates and Peters, 2007). This includes monthly water column sampling for DIC and total alkalinity (TA), with analysis of samples at the Bermuda Institute of Ocean Sciences (BIOS) using highly precise and accurate coulometric and potentiometric techniques, respectively (Bates et al., 1996a, b, 2012; Bates, 2001). DIC is defined as (Dickson et al., 2007):

$\mathrm{DIC}=\left[\mathrm{CO}_{2}^{*}\right]+\left[\mathrm{HCO}_{3}^{-}\right]+\left[\mathrm{CO}_{3}^{2-}\right]$

where $\left[\mathrm{CO}_{2} *\right]$ represents the concentration of all unionized carbon dioxide, whether present as $\mathrm{H}_{2} \mathrm{CO}_{3}$ or as $\mathrm{CO}_{2}$. The total alkalinity (TA) of seawater is defined as:

$$
\begin{aligned}
\mathrm{TA}= & {\left[\mathrm{HCO}_{3}^{-}\right]+2\left[\mathrm{CO}_{3}^{2-}\right]+\left[\mathrm{B}(\mathrm{OH})_{4}^{-}\right]+\left[\mathrm{OH}^{-}\right]+} \\
& {\left[\mathrm{HPO}_{4}^{2}-\right]+2\left[\mathrm{PO}_{4}^{3-}\right]+\left[\mathrm{SiO}(\mathrm{OH})_{3}^{-}\right]+\left[\mathrm{HS}^{-}\right]+} \\
& {\left[\mathrm{NH}_{3}\right]+\ldots-\left[\mathrm{H}^{+}\right]-\left[\mathrm{HSO}_{4}^{-}\right]-[\mathrm{HF}]-\left[\mathrm{H}_{3} \mathrm{PO}_{4}\right]-\ldots }
\end{aligned}
$$

where $\left[\mathrm{HCO}_{3}^{-}\right],\left[\mathrm{CO}_{3}^{2-}\right]$, and $\left[\mathrm{B}(\mathrm{OH})_{4}^{-}\right]$are the principal components of seawater TA. 


\subsection{Sampling frequency at BATS}

The frequency of sampling at BATS was not uniform in time. Beginning in 1988, samples were collected 9-12 times a year but not always at the depth of the STMW, but the sampling frequency increased to 14-15 times a year over the last 15 years. The time-series of DIC in STMW is not weighted to spring conditions, unlike surface observations where seasonality exerts significant influence on trends in seawater carbonate chemistry (Bates et al., 2012).

\subsection{Sampling methods}

Samples from the BATS site were collected into $500 \mathrm{ml}$ Pyrex bottles, poisoned with $\mathrm{HgCl}_{2}$, sealed with ground glass stoppers and subsequently analyzed at BIOS (Bates et al., 1996a; Bates, 2007). Since the early 2000s, smaller Pyrex bottles $(350 \mathrm{ml})$ were used. Samples were typically analyzed within a few months of collection.

\subsection{Analytical methods}

At BIOS, DIC was determined using coulometric methods with a SOMMA system (Bates et al., 1996a; Bates, 2007). During the first two years of sampling (1988-1990), DIC samples from BATS cruises 1 to 21 were analyzed at WHOI, and thereafter at BIOS. Each day of analysis, DIC was calibrated with known volumes of pure $\mathrm{CO}_{2}$ gas, and certified reference materials (CRMs; Dickson et al., 2007) were routinely analyzed each day of analysis. Potentiometric titration methods were also used for determination of alkalinity at BIOS (Bates et al., 1996b). In the 1990s, a manual alkalinity titrator was used, replaced by an automated VINDTA $2 \mathrm{~S}$ (Versatile Instrument for the Determination of Titration Alkalinity; manufactured by Marianda Co.) in the early 2000s. In both systems, at least 15-20 titration points past the carbonic acid end point were determined for each sample, and TA was then computed using non-linear least squares methods (Dickson et al., 2007). Surface water from Sargasso Sea was typically used to condition the titrator while CRMs were routinely used. Analytical precision for both DIC and TA at BIOS was typically $<0.2 \%$ for more than 1000 withinbottle and between-bottle replicate analyses.

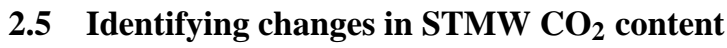

The time-series of seawater carbonate chemistry for STMW was compiled using temperature criteria (i.e. $17.8-18.4^{\circ} \mathrm{C}$ ) to identify STMW water, as in previous studies (Bates et al., 2002). During a few cruises, total alkalinity was not determined analytically, but it was computed from salinity with an error of $2.8 \mu$ moles $\mathrm{kg}^{-1}$ (Bates et al., 1996b; $\mathrm{TA}=-47.155+66.576 \times S)$.

\subsection{Seawater carbonate chemistry computations}

The complete seawater carbonic acid system (i.e. $\mathrm{CO}_{2}$, $\mathrm{H}_{2} \mathrm{CO}_{3}, \mathrm{HCO}_{3}^{-}, \mathrm{CO}_{3}^{2-}$, and $\mathrm{H}^{+}$) can be calculated from a combination of two carbonate system parameters (i.e. DIC, $\mathrm{TA}, p \mathrm{CO}_{2}$ and/or $\mathrm{pH}$ ) and temperature and salinity. Seawater $p \mathrm{CO}_{2}, \mathrm{pH},\left[\mathrm{CO}_{3}^{2-}\right]$, mineral saturation states for calcite $\left(\Omega_{\text {calcite }}\right)$ and aragonite $\left(\Omega_{\text {aragonite }}\right)$, and the Revelle factor $\left(\beta ;=\partial \ln p \mathrm{CO}_{2} / \partial \ln\right.$ DIC) were computed from DIC, TA, temperature and salinity data using the program $\mathrm{CO} 2 \mathrm{calc}$ (Robbins et al., 2010). The carbonic acid dissociation constants of Mehrbach et al. (1973) as refit by Dickson and Millero (1987) was used for the computation, as well as dissociation constants for $\mathrm{HSO}_{4}^{-}$(Dickson, 1990). Here, $p \mathrm{CO}_{2}$ is the partial pressure of $\mathrm{CO}_{2}$ in equilibrium with seawater, while $\mathrm{pH}$ is expressed on the total seawater scale.

Salinity normalized DIC (i.e. nDIC) and TA (i.e. nTA) data were also determined to account for local evaporation and precipitation changes. Trends and regression statistics for $\mathrm{CO}_{2}$ changes in the STMW are given in Table 1 (using a 17.8-18.4 ${ }^{\circ} \mathrm{C}$ temperature criterion to define STMW; Fig. 2; Table 1). A density criterion (i.e. $26.4 \sigma_{\Theta}$ isopycnal surface) can also be used to define STMW but does not give significantly different results. Surface trends are also discussed here for comparative purposes, but more detailed information about surface seawater carbonate chemistry changes are given elsewhere (Bates et al., 2012).

\subsection{Trend analysis and statistics}

Trend analysis was performed with observed data for STMW (Table 1). Trends were also computed for the two time periods (1988-2000; 2000-2011; Table 2). Regression statistics given were slope, error, $r^{2}, p$-value and $n$. Trends with pvalues greater than 0.01 were deemed statistically not significant. Monthly and winter JFM (January, February, March) mean NAO index data was obtained from the NOAA Climate Prediction Office (http://www.cpc.ncep.noaa.gov/products/ precip/CWlink/pna/nao_index.html). Correlations between winter NAO, mixed layer depth, and surface and STMW DIC contents are shown in Table 3. Mixed layer depth (MLD) was computed from the depth at which temperature was less than $0.5^{\circ} \mathrm{C}$ cooler than surface temperatures.

\section{Results}

\subsection{Seawater carbonate chemistry changes in STMW}

Over the last 2 decades (1988-2011), the inorganic carbon content of STMW, such as DIC (i.e. DIC ${ }^{\mathrm{STMW}}$ ) and $p \mathrm{CO}_{2}$, has significantly changed while temperature, salinity and total alkalinity did not change significantly over time (Fig. 2a; Table 1). Short-term changes (Bates et al., 1996b) and longer term trends in total alkalinity have been observed in surface waters but not at depth in the STMW. For example, 
Table 1. Long-term trends (1988-2011) of STMW hydrography and seawater carbonate chemistry with regression statistics (slope and error, $n, r^{2}$ and p-value). This table includes trend analyses of STMW including temperature, salinity, seawater carbonate chemistry (i.e. DIC, nDIC, TA, nTA, atmospheric $p \mathrm{CO}_{2}\left(p \mathrm{CO}_{2}^{\text {atm }}\right)$, calculated seawater $p \mathrm{CO}_{2}\left(p \mathrm{CO}_{2}^{\text {sea }}\right)$ and Revelle factor $(\beta)$ anomalies $)$, and indicators of seawater carbonate chemistry changes (i.e. $\mathrm{pH},\left[\mathrm{CO}_{3}^{2-}\right]$, and mineral saturation states of calcite $\left(\Omega_{\text {calcite }}\right)$ and aragonite $\left.\left(\Omega_{\text {aragonite }}\right)\right)$ from the BATS $\left(31^{\circ} 40^{\prime} \mathrm{N}, 64^{\circ} 10^{\prime} \mathrm{W}\right)$ site in the North Atlantic Ocean. Please see text for details on the seawater carbonate chemistry computation and salinity normalization procedures.

\begin{tabular}{|c|c|c|c|c|c|c|c|}
\hline Parameter & Period & $\begin{array}{l}\text { Mean } \\
\text { (std dev) }\end{array}$ & $\begin{array}{l}\text { 1988-2011 } \\
\text { change }\end{array}$ & $\begin{array}{l}\text { Slope and } \\
\text { std error }\end{array}$ & $n$ & $r^{2}$ & p-value \\
\hline \multicolumn{8}{|l|}{ Hydrography } \\
\hline Temperature & Sep 1988-Jul 2011 & $18.10 \pm 0.17^{\circ} \mathrm{C}$ & -0.26 & $-0.011 \pm 0.002^{\circ} \mathrm{C} \mathrm{yr}^{-1}$ & 214 & 0.14 & $<0.01$ \\
\hline Salinity & Sep 1988- Jul 2011 & $36.540 \pm 0.035$ & 0.015 & $0.0006 \pm 0.0004 \mathrm{yr}^{-1}$ & 214 & 0.01 & 0.13 \\
\hline \multicolumn{8}{|c|}{ Seawater carbonate chemistry } \\
\hline DIC & Sep 1988-Jul 2011 & $2098.09 \pm 11.1 \mu \mathrm{mol} \mathrm{kg}-1$ & +34.6 & $+1.51 \pm 0.08 \mu \mathrm{mol} \mathrm{kg}^{-1} \mathrm{yr}^{-1}$ & 209 & 0.63 & $<0.01$ \\
\hline DIC & Sep 1988-May 2010 & $2098.06 \pm 11.4 \mu \mathrm{mol} \mathrm{kg}-1$ & +40.0 & $+1.74 \pm 0.08 \mu \mathrm{mol} \mathrm{kg}^{-1} \mathrm{yr}^{-1}$ & 195 & 0.73 & $<0.01$ \\
\hline $\mathrm{nDIC}$ & Sep 1988-Jul 2011 & $2101.6 \pm 11.5 \mu \mathrm{mol} \mathrm{kg}^{-1}$ & +33.6 & $+1.46 \pm 0.09 \mu \mathrm{mol} \mathrm{kg}^{-1} \mathrm{yr}^{-1}$ & 209 & 0.55 & $<0.01$ \\
\hline TA & Sep 1988-Jul 2011 & $2387.4 \pm 5.3 \mu \mathrm{mol} \mathrm{kg}-1$ & +3.6 & $+0.15 \pm 0.06 \mu \mathrm{mol} \mathrm{kg}-1 \mathrm{yr}^{-1}$ & 208 & 0.03 & 0.02 \\
\hline nTA & Sep 1988-Jul 2011 & $2391.2 \pm 4.9 \mu \mathrm{mol} \mathrm{kg}-1$ & +2.4 & $+0.11 \pm 0.06 \mu \mathrm{mol} \mathrm{kg}^{-1} \mathrm{yr}^{-1}$ & 208 & 0.02 & 0.07 \\
\hline$p \mathrm{CO}_{2}^{\mathrm{sea}}$ & Sep 1988-Jul 2011 & $354.4 \pm 18.5 \mu \mathrm{atm}$ & +48.9 & $+2.13 \pm 0.16 \mu \mathrm{atm} \mathrm{yr}^{-1}$ & 208 & 0.45 & $<0.01$ \\
\hline Revelle $(\beta)$ & Sep 1988-Jul 2011 & $10.07 \pm 0.22$ & +0.58 & $+0.025 \pm 0.002 \mathrm{yr}^{-1}$ & 208 & 0.44 & $<0.01$ \\
\hline \multicolumn{8}{|c|}{ Ocean acidification indicators } \\
\hline $\mathrm{pH}$ & Sep 1988-Jul 2011 & $8.078 \pm 0.020$ & -0.053 & $-0.0022 \pm 0.0002 \mathrm{yr}^{-1}$ & 208 & 0.44 & $<0.01$ \\
\hline $\mathrm{CO}_{3}^{2-}$ & Sep 1988-Jul 2011 & $204.68 \pm 7.9 \mu \mathrm{mol} \mathrm{kg}-1$ & -20.0 & $-0.87 \pm 0.07 \mu \mathrm{mol} \mathrm{kg}^{-1} \mathrm{yr}^{-1}$ & 208 & 0.41 & $<0.01$ \\
\hline$\Omega_{\text {calcite }}$ & Sep 1988-Jul 2011 & $2.99 \pm 0.13$ & -0.33 & $-0.022 \pm 0.0019 \mathrm{yr}^{-1}$ & 208 & 0.40 & $<0.01$ \\
\hline$\Omega_{\text {aragonite }}$ & Sep 1988-Jul 2011 & $4.59 \pm 0.20$ & -0.51 & $-0.014 \pm 0.0012 \mathrm{yr}^{-1}$ & 208 & 0.40 & $<0.01$ \\
\hline
\end{tabular}

Table 2. Long-term trends of STMW hydrography and seawater carbonate chemistry with regression statistics (slope and error, $n, r^{2}$ and p-value) separated into time-periods (1988-2011; 1988-2000; 2001-2011).

\begin{tabular}{lllrrr}
\hline Parameter & Period & Slope and std error & $n$ & $r^{2}$ & p-value \\
\hline 1988-2011 & & & & & \\
\hline Temperature & Sep 1988-Jul 2011 & $-0.011 \pm 0.002^{\circ} \mathrm{C} \mathrm{yr}^{-1}$ & 214 & 0.14 & $<0.01$ \\
Salinity & Sep 1988-Jul 2011 & $+0.0064 \pm 0.0004 \mathrm{yr}^{-1}$ & 212 & 0.01 & 0.13 \\
Dissolved oxygen & Sep 1988-Mar 2009 & $-0.15 \pm 0.07 \mu \mathrm{mol} \mathrm{kg}^{-1} \mathrm{yr}^{-1}$ & 227 & 0.02 & 0.04 \\
Nitrate & Sep 1988-Mar 2009 & $+0.01 \pm 0.01 \mu \mathrm{mol} \mathrm{kg}^{-1} \mathrm{yr}^{-1}$ & 219 & 0.01 & 0.26 \\
DIC & Sep 1988-Jul 2011 & $+1.51 \pm 0.08 \mu \mathrm{mol} \mathrm{kg}^{-1} \mathrm{yr}^{-1}$ & 209 & 0.63 & $<0.01$ \\
DIC & Sep 1988-Jul 2010 & $+1.74 \pm 0.08 \mu \mathrm{mol} \mathrm{kg}^{-1} \mathrm{yr}^{-1}$ & 196 & 0.73 & $<0.01$ \\
\hline 1988-2001 & & & & & \\
\hline Temperature & Sep 1988-Jul 2001 & $-0.019 \pm 0.005^{\circ} \mathrm{C} \mathrm{yr}^{-1}$ & 87 & 0.17 & $<0.01$ \\
Salinity & Sep 1988-Jul 2001 & $-0.0014 \pm 0.0008 \mathrm{rr}^{-1}$ & 86 & 0.32 & $<0.01$ \\
Dissolved oxygen & Sep 1988-Jul 2001 & $-0.55 \pm 0.14 \mu \mathrm{mol} \mathrm{kg}^{-1} \mathrm{yr}^{-1}$ & 144 & 0.10 & $<0.01$ \\
Nitrate & Sep 1988-Jul 2001 & $+0.03 \pm 0.02 \mu \mathrm{mol} \mathrm{kg}^{-1} \mathrm{yr}^{-1}$ & 139 & 0.02 & 0.14 \\
DIC & Sep 1988-Jul 2001 & $+2.06 \pm 0.21 \mu \mathrm{mol} \mathrm{kg}^{-1} \mathrm{yr}^{-1}$ & 85 & 0.53 & $<0.01$ \\
\hline 2001-2011 & & & & & \\
\hline Temperature & Jul 2001-Jul 2011 & $+0.007 \pm 0.005^{\circ} \mathrm{C} \mathrm{yr}^{-1}$ & 127 & 0.01 & 0.23 \\
Salinity & Jul 2001-Mar 2009 & $+0.006 \pm 0.001 \mathrm{yr}^{-1}$ & 127 & 0.17 & $<0.01$ \\
Dissolved oxygen & Jul 2001-Mar 2009 & $+1.29 \pm 0.27 \mu \mathrm{mol} \mathrm{kg}^{-1} \mathrm{rr}^{-1}$ & 84 & 0.21 & $<0.01$ \\
Nitrate & Jul 2001-Jul 2011 & $-0.05 \pm 0.04 \mu \mathrm{mol} \mathrm{kg}^{-1} \mathrm{yr}^{-1}$ & 78 & 0.02 & 0.28 \\
DIC & Jul 2001-Jul 2011 & $+0.56 \pm 0.21 \mu \mathrm{mol} \mathrm{kg}^{-1} \mathrm{yr}^{-1}$ & 124 & 0.06 & $<0.01$ \\
\hline
\end{tabular}




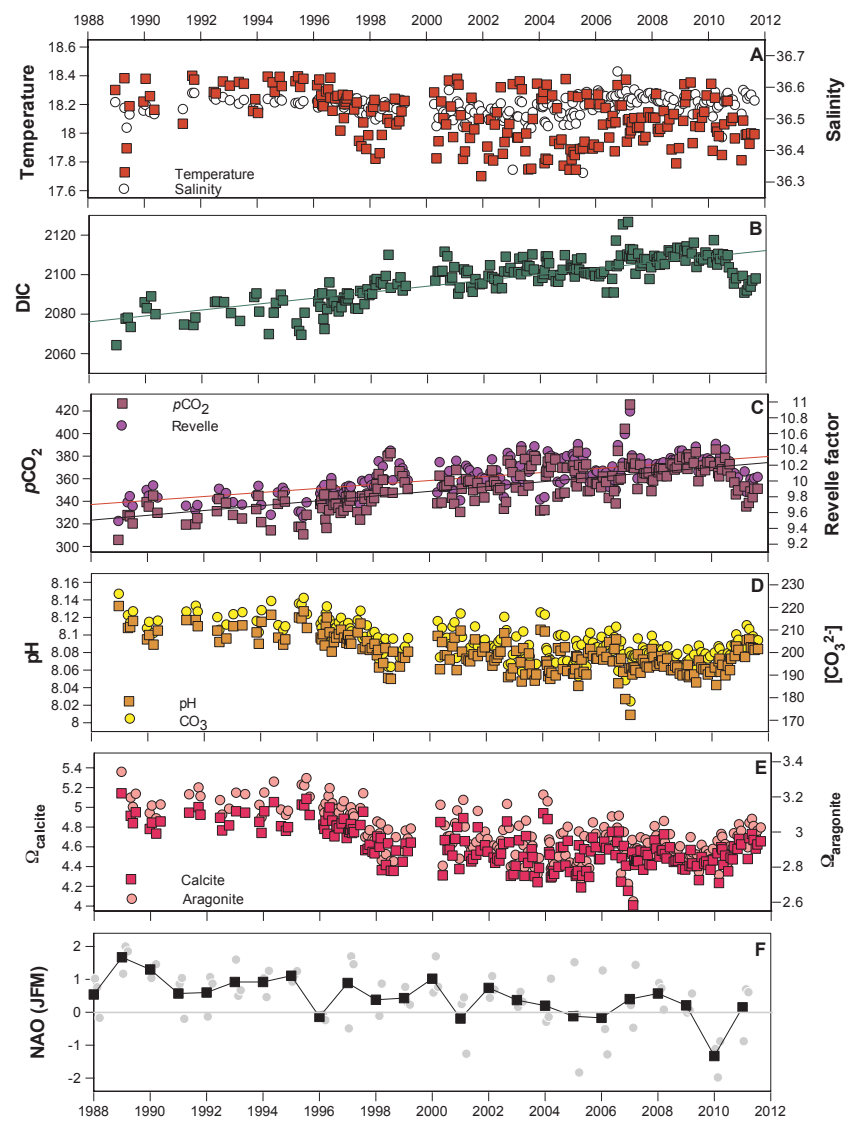

Fig. 2. Long-term observations and trends of STMW hydrography, seawater carbonate chemistry and ocean acidification indicators from 1988 to 2011 at the BATS (Bermuda Atlantic Time-series Study; $31^{\circ} 40^{\prime} \mathrm{N}, 64^{\circ} 10^{\prime} \mathrm{W}$ ) site located near Bermuda in the NW Atlantic Ocean. Slopes and statistics of regressions are listed in Table 1. (A) Sea surface temperature $\left({ }^{\circ} \mathrm{C}\right.$; black symbol) and salinity (red symbol). (B) Surface dissolved inorganic carbon (DIC, $\mu \mathrm{mol} \mathrm{kg}{ }^{-1}$, green symbol). (C) Seawater $p \mathrm{CO}_{2}$ ( $\mu$ atm; purple symbol) and Revelle factor $(\beta)$ (fuchsia symbol). (D) Surface seawater $\mathrm{pH}$ (orange symbol) and $\left[\mathrm{CO}_{3}^{2-}\right]\left(\mu \mathrm{mol} \mathrm{kg}{ }^{-1}\right.$, yellow symbol). (E) Surface saturation state of calcite $\left(\Omega_{\text {calcite }}\right)$ (pink symbol) and aragonite $\left(\Omega_{\text {aragonite }}\right)$ (light pink symbol). (F) time-series of January, February and March NAO index (grey circles) and mean winter NAO (JFM; black square symbols and line).

the long-term trends of DIC (i.e. $\delta \mathrm{DIC}^{\mathrm{STMW}} / \delta t_{1988-2011}$ ) and salinity normalized nDIC in STMW exhibit increases of $+1.51 \pm 0.08$ and $+1.46 \pm 0.06 \mu \mathrm{mol} \mathrm{kg}^{-1} \mathrm{yr}^{-1}$, respectively. This constitutes a $40 \mu$ moles kg ${ }^{-1}$ change in DIC $^{\text {STMW }}$ since 1988 (Fig. 2b). Contemporaneously, the computed seawater $p \mathrm{CO}_{2}$ of STMW increased at a rate of $+2.13 \pm 0.16 \mu$ atm kg $\mathrm{kg}^{-1} \mathrm{yr}^{-1}$ (an increase of nearly $50 \mu \mathrm{atm}$ or $12 \%$ from 1988 to 2011; Fig. 2c), which is higher than the increase in atmospheric $p \mathrm{CO}_{2}$ observed over the same period $\left(+1.72 \pm 0.01 \mu\right.$ atm yr ${ }^{-1}$; Bates et al., 2012). The Revelle factor $(\beta)$, which indicates the capacity of seawater to absorb $\mathrm{CO}_{2}$, has also increased at a rate of $+0.025 \pm 0.002 \mathrm{yr}^{-1}$
Table 3. Correlation table of selected mean winter (JFM) variables. Within each cell, the first row is the correlation coefficient and second row is the $\mathrm{p}$-value. For each correlation, $N=22-23$. Only those correlations with $P \leq 0.1$ are shown, with $P \leq 0.01$ in bold.

\begin{tabular}{|c|c|c|c|c|}
\hline & MLD & DIC $C^{\text {surface }}$ & DIC STMW & DIC STMW-surf \\
\hline \multirow[t]{2}{*}{ NAO } & -0.34 & -0.66 & $-\mathbf{0 . 3 0}$ & 0.45 \\
\hline & $<0.01$ & $<\mathbf{0 . 0 1}$ & $<\mathbf{0 . 0 1}$ & $<0.01$ \\
\hline \multirow[t]{2}{*}{ MLD } & & 0.23 & - & -0.39 \\
\hline & & 0.02 & & $<0.01$ \\
\hline \multirow[t]{2}{*}{ DIC ${ }^{\text {surface }}$} & & 0.63 & -0.32 & \\
\hline & & & $<0.01$ & $<\mathbf{0 . 0 1}$ \\
\hline DIC ${ }^{\text {STMW }}$ & & & - & \\
\hline
\end{tabular}

(Fig. 2c). This infers that the capacity of STMW to absorb $\mathrm{CO}_{2}$ has gradually reduced over time, similar to the model studies of Thomas et al. (2007).

\subsection{Detecting rates of ocean acidification in STMW}

Trend analysis indicates that relevant indicators of ocean acidification in STMW such as $\mathrm{pH}$ have also significantly decreased. The $\mathrm{pH}$ of STMW decreased at a rate of $-0.0022 \pm 0.0002 \mathrm{yr}^{-1}$, a seawater $\mathrm{pH}$ decline of 0.05 over the past 2 decades (Fig. 2d; Table 1). This rate of $\mathrm{pH}$ decrease is higher than that for surface waters at BATS $\left(-0.0017 \pm 0.0001 \mathrm{yr}^{-1}\right)$ as well as off Hawaii and the $\mathrm{Ca}-$ nary Islands $\left(-0.0014\right.$ to $-0.0019 \mathrm{yr}^{-1}$ ) (Dore et al., 2009; González-Dávila et al., 2010). This change in $\mathrm{pH}$ of the STMW represents a $12 \%$ increase in hydrogen ions $\left(\mathrm{H}^{+}\right)$ since 1988. Other indicators of ocean acidification at BATS such as $\left[\mathrm{CO}_{3}^{2-}\right], \Omega_{\text {calcite }}$ and $\Omega_{\text {aragonite }}$ have also decreased by $-0.87 \pm 0.07 \mu \mathrm{mol} \mathrm{kg} \mathrm{yr}^{-1},-0.022 \pm 0.002 \mathrm{yr}^{-1}$, and $-0.014 \pm 0.001 \mathrm{yr}^{-1}$, respectively (Fig. 2d and e; Table 1). The ecosystem response in the mesopelagic (i.e. at the depth of STMW within the subtropical gyre) to ocean acidification is unknown at present.

\section{Discussion}

\subsection{Determining the rates of $\mathrm{CO}_{2}$ uptake into STMW over the last 2 decades}

Trend analyses reveal that DIC ${ }^{\text {STMW }}$ has increased at a significantly higher rate than observed for surface waters in the subtropical gyre (1988-2011). For example, the DIC of surface waters (i.e. DIC $\left.{ }^{\text {surface }}\right)$, expressed here as $\delta \mathrm{DIC}^{\text {surface }} / \delta t_{1988-2011}$, increased at a rate of $+1.08 \pm 0.05 \mu \mathrm{mol} \mathrm{kg}^{-1} \mathrm{yr}^{-1}$ (Bates et al., 2012; Fig. 3a). This trend is similar to that expected from equilibration of STMW with increasing atmospheric $\mathrm{CO}_{2}$ due to the anthropogenic $\mathrm{CO}_{2}$ transient. Here, this term (i.e. $\left.\delta \mathrm{DIC} \mathrm{C}^{\text {anthropogenic }} / \delta t_{1988-2011}\right)$ is calculated using mean hydrographic, DIC and TA values for STMW 

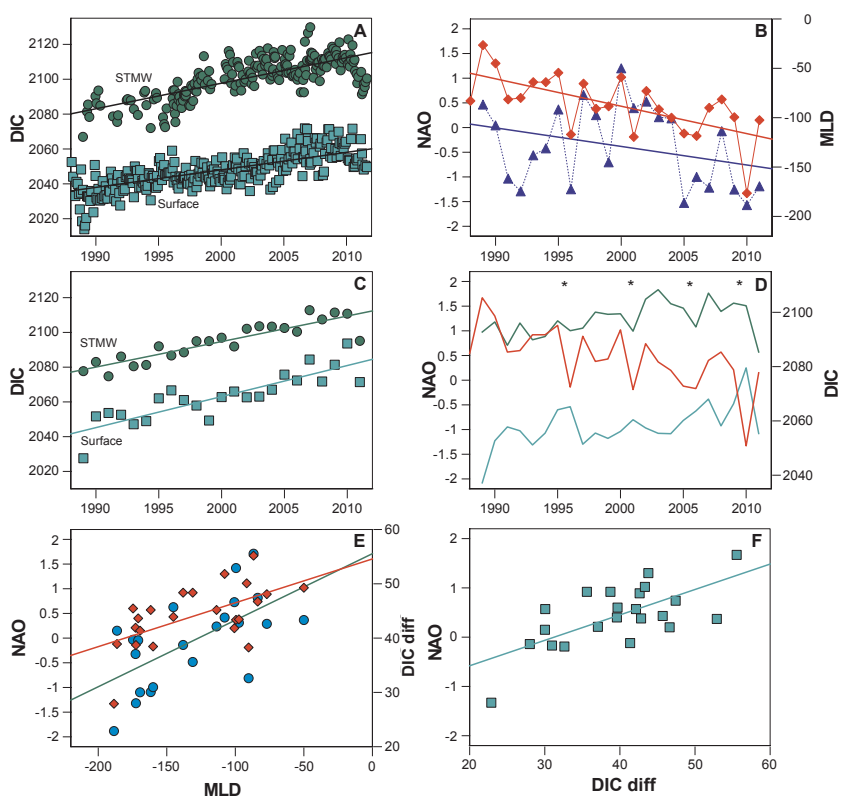

Fig. 3. Time-series and relationships between DIC, mixed layer depths (MLD) and NAO index from 1988 to 2011 at the BATS (Bermuda Atlantic Time-series Study; $31^{\circ} 40^{\prime} \mathrm{N}, 64^{\circ} 10^{\prime} \mathrm{W}$ ) site located near Bermuda in the NW Atlantic Ocean. Slopes and statistics of regressions are listed in Table 1. (A) Time-series of DIC in surface (DIC ${ }^{\text {surface}} ; \mu \mathrm{mol} \mathrm{kg}{ }^{-1}$; light green symbols) and STMW (DIC ${ }^{\mathrm{STMW}} ; \mu \mathrm{mol} \mathrm{kg}{ }^{-1}$; dark green symbols) waters. (B) Timeseries of winter NAO (JFM; red symbols and line) and mixed layer depth ( $\mathrm{m}$; blue symbols and line). (C) Time-series of winter (JFM) DIC in surface ( $\mu \mathrm{mol} \mathrm{kg}^{-1}$; light green symbols and line) and STMW ( $\mu \mathrm{mol} \mathrm{kg}{ }^{-1}$; dark green symbols and line) waters. (D) Time series of winter (JFM) DIC in surface ( $\mu \mathrm{mol} \mathrm{kg}-1$; light green line) and STMW ( $\mu \mathrm{mol} \mathrm{kg}^{-1}$; dark green line) waters and winter NAO (JFM; red line). The surface and STMW DIC data are corrected for long-term trends and so represent anomalies relative to longterm trends. (E). Scatterplot of winter (JFM) NAO (red symbols) and DIC difference between STMW and surface $\left(\mu \mathrm{mol} \mathrm{kg}^{-1}\right.$; blue symbols) against mixed layer depth $(\mathrm{m})$. (F). Scatterplot of winter (JFM) NAO against DIC difference between surface and STMW ( $\mu \mathrm{mol} \mathrm{kg}{ }^{-1}$; green symbols).

with the observed atmospheric $p \mathrm{CO}_{2}$ increases (due to anthropogenic $\mathrm{CO}_{2}$ ) over the same time 19882011 period (i.e. $+1.72 \pm 0.01 \mathrm{ppm} \mathrm{yr}^{-1}$ ). The trend for $\delta \mathrm{DIC}^{\text {anthropogenic }} / \delta t_{1988-2011}$ is $+1.06 \mu \mathrm{mol} \mathrm{kg}^{-1} \mathrm{yr}^{-1}$, and this effectively represents the uptake rate of anthropogenic $\mathrm{CO}_{2}\left(C_{\text {ant }}\right)$ from the atmosphere.

Examination of trends in seawater carbonate chemistry indicate that the DIC content of surface and STMW waters observed at the BATS site have increased at divergent rates over the last 2 decades (Fig. 3a). Once STMW is formed during winter, isopycnal mixing and subduction adds to the existing pool of STMW found between surface/seasonal thermocline waters and the permanent thermocline in the subtropical gyre (approximately
250-450 m deep). STMW is ultimately subducted to deeper depths with time (Behringer and Stommel, 1980; Spall, 1992; Fig. 4a). Using the $\delta \mathrm{DIC}^{\mathrm{STMW}} / \delta t_{1988-2011}$ trend of $+1.51 \pm 0.08 \mu \mathrm{mol} \mathrm{kg}^{-1} \mathrm{yr}^{-1}$, and given that the volume of STMW in the North Atlantic subtropical gyre is about 75 Svy (Forget et al., 2011), it is estimated that the STMW has accumulated $0.985 \pm 0.018 \mathrm{Pg} \mathrm{C}$ since 1988 (Fig. 4b). The error in the amount of $\mathrm{CO}_{2}$ taken up into STMW relates to that propagated from the trend error. However, the volume of STMW could be underestimated by $10 \%$ (Forget et al., 2011), which implies that the estimate of $0.985 \pm 0.018 \mathrm{Pg} \mathrm{C}$, and other estimations discussed later in the paper, may be higher by $10 \%$. The separation of STMW from contact with the atmosphere within the subtropical gyre (with exceptions discussed later) and eventual subduction to deeper waters constitutes a mechanism for transferring $\mathrm{CO}_{2}$ from the airsea interface to the deep ocean, and thus constitutes a sink for $\mathrm{CO}_{2}$. The sink of $\mathrm{CO}_{2}$ into the STMW, averaged annually for the period $1988-2011\left(0.042 \mathrm{Pg} \mathrm{Cyr}^{-1}\right)$, is approxiamtely $20 \%$ of the $\mathrm{CO}_{2}$ uptake in the North Atlantic Ocean in the zone between $14^{\circ}$ and $50^{\circ} \mathrm{N}\left(0.220 \mathrm{Pg} \mathrm{C} \mathrm{yr}^{-1}\right.$; Takahashi et al., 2009). Thus, over the last 2 decades, the STMW has been a quantitatively important additional $\mathrm{CO}_{2}$ sink term in the sink-source $\mathrm{CO}_{2}$ budget of the North Atlantic Ocean.

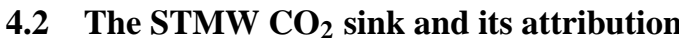

The change in DIC content of the STMW (i.e. $\left.\delta \mathrm{DIC}^{\mathrm{STMW}} / t_{1988-2011}\right)$ potentially results from a number of factors, including: (1) equilibration at the STMW outcrop with the anthropogenic $\mathrm{CO}_{2}$ increase in the atmosphere (i.e. $\delta \mathrm{DIC}^{\text {anthropogenic }} / t_{1988-2011}$ ); (2) physical changes at the outcrop site of STMW winter formation encompasses the summed changes due to variability in air-sea gas exchange of $\mathrm{CO}_{2}$, the preformed DIC content of waters that contribute to STMW formation during winter, formation rate of STMW and its subsequent dispersion rates in the subtropical gyre (here termed $\delta \mathrm{DIC}^{\text {outcrop }} / t_{1988-2011}$ ), and; (3) changes imparted by biological processes, including respiration/remineralization, acting on STMW during its transit through the subtropical gyre (here termed $\delta$ DIC $\left.^{\text {biology }} / t_{1988-2011}\right)$. Thus:

$$
\begin{aligned}
& \delta \mathrm{DIC}^{\mathrm{STMW}} / t_{1988-2011}= \\
& \delta \mathrm{DIC}^{\text {anthropogenic }} / t_{1988-2011}+\delta \mathrm{DIC}^{\text {biology }} / t_{1988-2011} \\
& +\delta \mathrm{DIC}^{\text {outcrop }} / t_{1988-2011}
\end{aligned}
$$

The $\delta$ DIC ${ }^{\text {anthropogenic }} / t_{1988-2011}$ term (Eq. 3) was estimated earlier at $1.06 \mu \mathrm{mol} \mathrm{kg} \mathrm{gr}^{-1}$, with the implication that the uptake of anthropogenic $\mathrm{CO}_{2}$ constitutes approximately $70 \%$ of the observed increase in DIC ${ }^{\text {STMW }}$. The rate of increase in atmopsheric $\mathrm{CO}_{2}$ at Bermuda has not changed significantly over the past couple of decades (Bates, 2007; Bates et al., 2012), and thus it is assumed that the equilibration rate of anthropogenic $\mathrm{CO}_{2}$ with surface waters 
A. STMW and subtropical gyre schematic

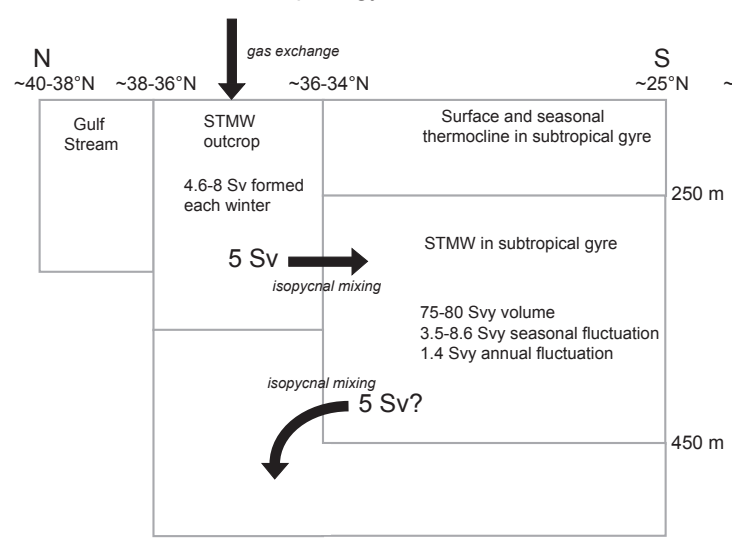

C. 1990-2001 STMW carbon sink (NAO +ve phase)

Enhanced long-term storage of anthropogenic $\mathrm{CO}_{2}$ sink into STMW during NAO +ve phases

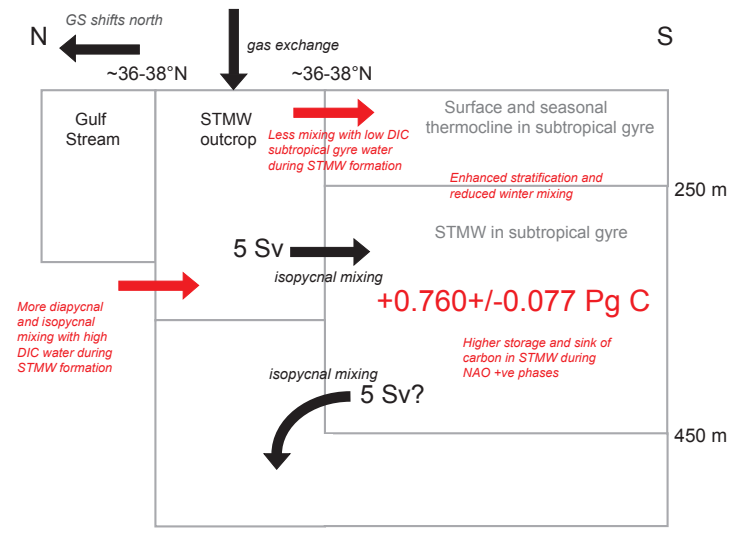

B. $1988-2011$ STMW carbon sink

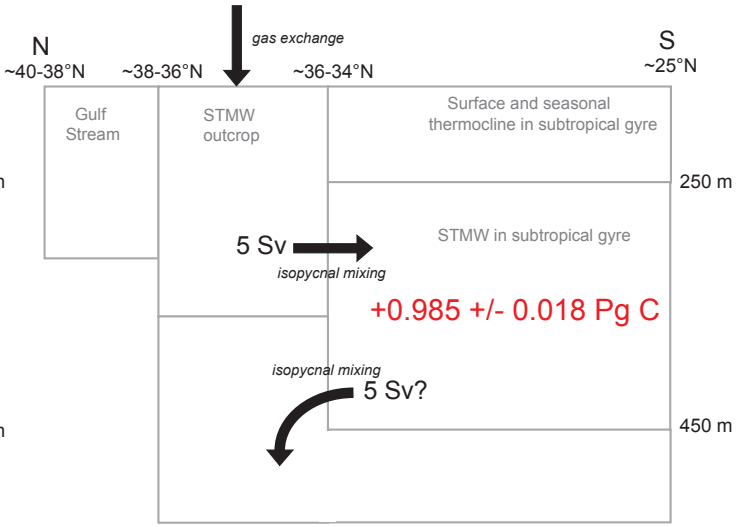

D. 2001-2011 STMW carbon sink (NAO neutral/negative)

Reduced anthropogenic $\mathrm{CO}_{2}$ sink into STMW during NAO neutral and -ve phases

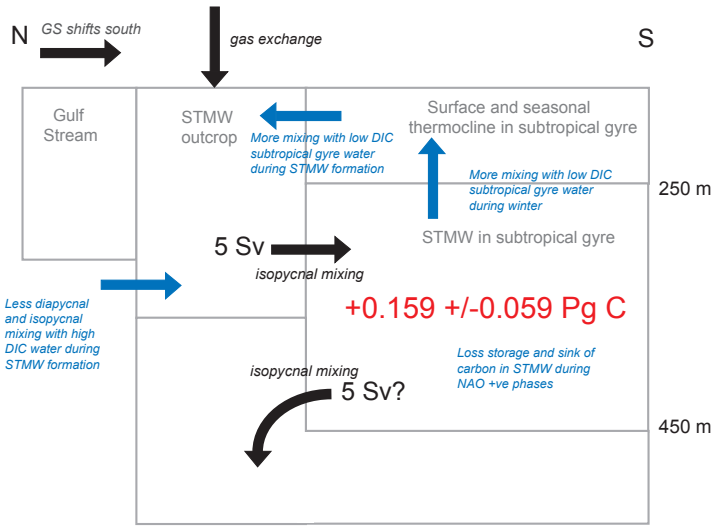

Fig. 4. Schematic of water masses and $\mathrm{CO}_{2}$ sink estimates in STMW for different time-periods from 1988-2011. (A) Schematic of North Atlantic subtropical gyre showing Gulf Stream, STMW outcrop, surface and seasonal thermocline layer (not to scale). Range of winter STMW formation rates (Sv; Speer and Tziperman, 1992; Kwon and Riser, 2004; Forget et al., 2011), volume of STMW (Svy; Maze et al., 2009; Forget et al., 2011), and seasonal/annual fluctuations in the volume of STMW (Kwon and Riser, 2004; Forget et al., 2011) are given. (B) Estimate of $\mathrm{CO}_{2}$ sink into STMW (Pg C) for 1988-2011 period. (C) Estimate of $\mathrm{CO}_{2}$ sink into STMW (Pg C) for 1988-2001 period. (D) Estimate of $\mathrm{CO}_{2}$ sink into STMW (Pg C) for 2001-2011 period.

(i.e. $\delta \mathrm{DIC}^{\text {anthropogenic }} / t_{1988-2011}$ ) has also not changed significantly. It is estimated that the uptake of anthropogenic $\mathrm{CO}_{2}$ into STMW since 1988 was $0.692 \pm 0.018 \mathrm{PgC}$ or approximately $70 \pm 1.8 \%$ of the total STMW $\mathrm{CO}_{2}$ sink $(0.985 \pm 0.018$ Pg C; Fig. 3b). The remaining terms in Eq. (1) comprise the remaining $30 \%$ of the observed changes.

Term two of Eq. (3) (i.e. $\delta$ DIC ${ }^{\text {biology }} / t_{1988-2011}$ ) can be approximated by examining changes in organic carbon export and remineralization and/or biogeochemical properties (e.g. dissolved oxygen and inorganic nutrients). Term three of Eq. (3) (i.e. $\delta$ DIC ${ }^{\text {outcrop }} / t_{1988-2011}$ ) is difficult to determine directly due to the lack of sustained observations at the STMW site of formation, but some field (Andersson et al., 2012) and model studies (Levine et al., 2011) provide some inferences on this term. Thus, Eq. (3) can be solved by difference, with the caveat that there are many uncertainties underlying this approach:

$$
\begin{aligned}
& \delta \mathrm{DIC}^{\text {outcrop }} / t_{1988-2011}= \\
& \delta \mathrm{DIC}^{\mathrm{STMW}} / t_{1988-2011}- \\
& \left(\delta \mathrm{DIC}^{\text {anthropogenic }} / t_{1988-2011}+\delta \mathrm{DIC}^{\text {biology }} / t_{1988-2011}\right)
\end{aligned}
$$

Since 1990, integrated rates of in situ primary production $(0-140 \mathrm{~m})$ have increased at BATS by $44 \%$ $\left(+0.85 \mathrm{mmol} \mathrm{C} \mathrm{m}^{-2} \mathrm{~d}^{-1} \mathrm{yr}^{-1}\right)$, and since 1996 by $98 \%$ (Lomas et al., 2010). During the 1990-2007 period, the sinking particulate organic carbon (POC) flux record at $150 \mathrm{~m}$ increased by $71 \%\left(+0.12 \mathrm{mmolC} \mathrm{m}^{-2} \mathrm{~d}^{-1} \mathrm{yr}^{-1}\right)$. However, at $300 \mathrm{~m}$, no long-term change was observed in POC flux (Lomas et al., 2010), with the implication that the observed increase in ocean carbon export is attenuated 
by mesopelagic remineralization of sinking organic carbon back to $\mathrm{CO}_{2}$ in the $150 \mathrm{~m}$ to $300 \mathrm{~m}$ depth zone. Since this depth zone coincides approximately with the upper/middle portion of the STMW, enhanced mesopelagic remineralization likely contributes to the observed increase in DIC ${ }^{\text {STMW }}$. Here, the increase in POC flux (i.e. $+0.12 \mathrm{mmol} \mathrm{C} \mathrm{m}^{-2} \mathrm{~d}^{-1} \mathrm{yr}^{-1}$ ) observed at BATS is converted to DIC change over time, assuming a $150 \mathrm{~m}$ thickness of STMW at BATS. The increase in DIC due to enhanced remineralization is estimated at $+0.29 \pm 0.05 \mu \mathrm{mol} \mathrm{kg}^{-1} \mathrm{yr}^{-1}$ (i.e. $\left.\delta \mathrm{DIC}^{\text {biology }} / t_{1988-2011}\right), \quad$ or $\quad$ approximately $19 \pm 3.2 \%$ of $\delta \mathrm{DIC}^{\mathrm{STMW}} / t_{1988-2011}$. Thus, it is estimated that the enhanced remineralization within STMW since 1988 has contributed $0.187 \pm 0.036 \mathrm{PgC}$ of the total STMW $\mathrm{CO}_{2}$ sink $(0.985 \pm 0.018 \mathrm{PgC}$; Fig. 4b). Dissolved oxygen (DO) and nitrate contents also changed by $-0.15 \pm 0.07 \mu \mathrm{mol} \mathrm{kg}^{-1} \mathrm{yr}^{-1}$ and $-0.01 \pm 0.01 \mu \mathrm{mol} \mathrm{kg}{ }^{-1} \mathrm{yr}^{-1}$, respectively $\quad\left(r^{2}<0.02\right)$. However, both DO and nitrate are also likely to vary depending on preconditioning and physical changes at the winter outcrop site of STMW formation. Despite these caveats, it appears that increase in DIC STMW due to changes at the STMW outcrop (i.e. term three in Eq. (3), $\delta \mathrm{DIC} \mathrm{Cutcrop}^{\text {out }} t_{1988-2011)}$ contributes the remaining $11 \%$ to $\delta \mathrm{DIC}^{\mathrm{STMW}} / t_{1988-2011}$ (i.e. $\left.\delta \mathrm{DIC}^{\text {outcrop }} / t_{1988-2011}=0.16=1.51-[1.06+0.29]\right)$, or approximately $0.099 \mathrm{Pg} \mathrm{C}$.

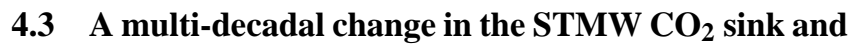 its relation to NAO variability}

A closer inspection of the trends in DIC ${ }^{\mathrm{STMW}}$ reveals considerable difference between the 1990s and 2000s. The trend for DIC ${ }^{\text {STMW }}$ determined for 1988 to 2001 was much higher at $2.06 \pm 0.26 \mu \mathrm{mol} \mathrm{kg} \mathrm{yr}^{-1}$ (Bates et al., 2002, and recalculated here) compared to that observed for the 2001 to 2011 period at $0.56 \pm 0.21 \mu \mathrm{mol} \mathrm{kg}{ }^{-1} \mathrm{yr}^{-1}$ (Fig. 3a; Table 2). Over the last 2 decades, the NAO (JFM) winter state has transitioned from mostly positive values in the 1990s to neutral and negative values in the 2000s (Fig. 3b). Contemporaneous with the change in winter NAO, the mean winter mixed layer depth (MLD) has also deepened significantly from 110 to $150 \mathrm{~m}$ (Fig. 3b). Notably, a significant decline in DIC ${ }^{\text {STMW }}$ was observed in 2011 that coincides with a strongly negative NAO (JFM) winter phase (Figs. 2f and $3 b)$. If data from 2011 is not included in the trend analysis, the $\delta \mathrm{DIC}^{\mathrm{STMW}} / t_{1988-2010}$ was significantly higher at $1.74 \pm 0.08 \mu \mathrm{mol} \mathrm{kg}^{-1} \mathrm{yr}^{-1}$ (see Table 1 ).

If winter DIC ${ }^{\text {STMW }}$ and surface DIC are compared, the trends are convergent (Fig. 3c) rather than divergent (Fig. 3a). While winter DIC ${ }^{\text {STMW }}$ trends are similar to those determined for all annual data $\left(+1.46 \mu \mathrm{mol} \mathrm{kg}{ }^{-1} \mathrm{yr}^{-1}\right)$, winter

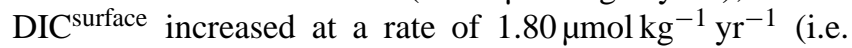
$0.70 \mu \mathrm{mol} \mathrm{kg} \mathrm{gr}^{-1}$ greater than the trend determined for DIC ${ }^{\text {surface }}$ with all monthly data; Table 1). As the winter NAO

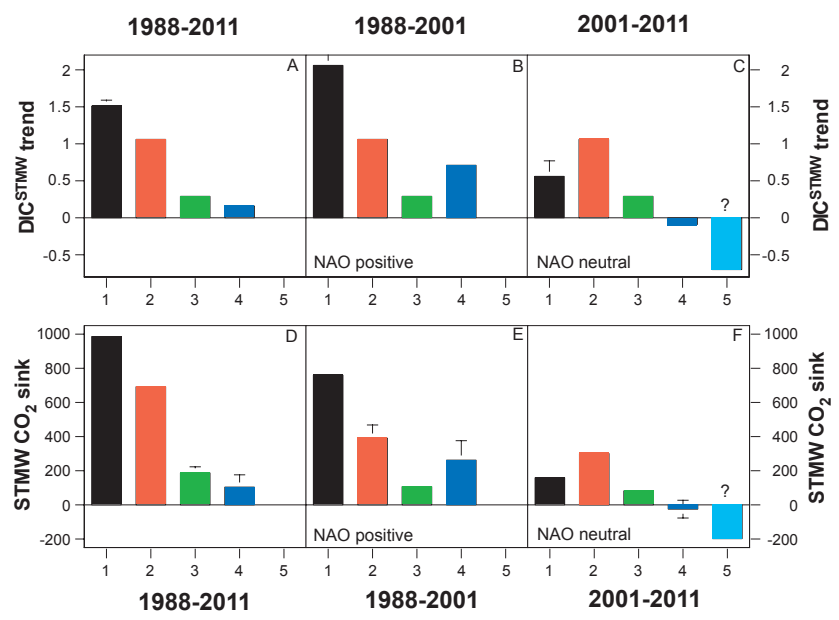

Fig. 5. Trends in DIC STMW (A-C; $\left.\mu \mathrm{mol} \mathrm{kg}^{-1} \mathrm{yr}^{-1}\right)$ and estimates of $\mathrm{CO}_{2}$ sink into STMW (D-F; Pg C) for the 1988-2011, 19882001, and 2001-2011 periods. The trend and $\mathrm{CO}_{2}$ sink in STMW is given in row 1 in each panel ( $\delta \mathrm{DIC} \mathrm{STMW}^{\mathrm{ST}} t$; black). In each panel, row 2 denotes potential uptake due to anthropogenic $\mathrm{CO}_{2}\left(\mathrm{C}_{\mathrm{ant}}\right.$ or $\delta \mathrm{DIC}^{\text {anthropogenic }} / t$; red) row 3 denotes increase due to remineralization of organic carbon in STMW to $\mathrm{CO}_{2}$ (i.e. $\delta$ DIC $\mathrm{C}^{\text {biology }} / t$; green); row 4 denotes increase (decrease) at the STMW outcrop (i.e. $\delta$ DIC ${ }^{\text {outcrop }} / t$; blue); and row 5 denotes the potential change due to mixing of STMW with surface/seasonal thermocline waters (i.e. $\left.\mathrm{dDIC}{ }^{\text {mixing }} / t\right)$.

has declined to neutral status over the last decade, winter DIC ${ }^{\text {surface }}$ has increased as mixed layers have deepened (with standout high values during NAO negative winters; Fig. 3d). In contrast, winter DIC ${ }^{\text {STMW }}$ appears to lag NAO by up to 1-2 yr (Levine et al., 2011), with the lag observed at BATS greater during NAO positive phases. NAO, mixed layer depth and the difference between surface and STMW DIC also appear well correlated with each other (Fig. 3e and f; $r^{2}$ values of 0.25-0.45; Table 3).

In the 1990s, contemporaneous with DIC ${ }^{\text {STMW }}$ increase of $2.06 \pm 0.26 \mu \mathrm{mol} \mathrm{kg} \mathrm{yr}^{-1}$ (Bates et al., 2002, and recalculated here; Fig. 5; Table 2), DO decreased and nitrate increased at $-0.55 \pm 0.14$ and $+0.03 \pm 0.02 \mu \mathrm{mol} \mathrm{kg}^{-1} \mathrm{yr}^{-1}$, respectively (although the $r^{2}$ values were low, $<0.10$ ). With the volume of STMW at 75 Svy (Forget et al., 2011), this is equivalent to an increase of $0.760 \pm 0.077 \mathrm{PgC}$ (Figs. $4 \mathrm{c}$ and $5 \mathrm{~d}$ ), or approximately $77 \pm 10 \%$ of the $1988-2011$ increase of DIC STMW. Thus, in the 1990s, the sink of $\mathrm{CO}_{2}$ into the STMW was $27 \%$ of the long-term $\mathrm{CO}_{2}$ uptake in the North Atlantic Ocean in the zone between $14^{\circ}$ and $50^{\circ} \mathrm{N}$ (i.e. $0.220 \mathrm{Pg} \mathrm{Cyr}^{-1}$; Takahashi et al., 2009). In contrast, the $\delta \mathrm{DIC}^{\mathrm{STMW}} / t_{2001-2011}$ trend was only $+0.56 \mu \mathrm{mol} \mathrm{kg}^{-1} \mathrm{yr}^{-1}$ for the 2000s (Fig. 5c). The increase in DIC ${ }^{\text {STMW }}$ is much reduced compared to the 1990s, as is the estimate of the $\mathrm{CO}_{2}$ sink into STMW of $0.159 \pm 0.059 \mathrm{Pg} \mathrm{C}$ (Figs. $4 \mathrm{~d}$ and 5e), or only about $7 \%$ of the North Atlantic Ocean $\mathrm{CO}_{2}$ sink between $14^{\circ}$ and $50^{\circ} \mathrm{N}$ (Takahashi et al., 2009). 
The two periods of observation, 1988-2001 and 20012011, correspond approximately to a decade of positive winter NAO (mean of $+0.73,1989-2001$ ) followed by a decade of neutral/negative NAO (mean of +0.10 , 20012011). Levine et al. (2011) suggest that STMW takes up more $\mathrm{CO}_{2}$ during NAO positive phase as the Gulf Stream and STMW outcrop move northward in response to NAO. During an NAO neutral to negative phase, the Gulf Stream and STMW outcrop move south with less $\mathrm{CO}_{2}$ taken up by STMW. Levine et al. (2011) show a STMW $\mathrm{CO}_{2}$ uptake variability of $0.100 \mathrm{Pg} \mathrm{Cyr}^{-1}$, depending on the state of the NAO.

In the 1990s, trend analyses and STMW sink $\mathrm{CO}_{2}$ estimates indicate that the accumulation of $\mathrm{CO}_{2}$ into STMW was large during the NAO positive phase, with $C_{\text {ant }}$ computed to be $0.391 \pm 0.077 \mathrm{Pg} \mathrm{C}$ or approximately $51 \pm 10 \%$ of the total $0.760 \mathrm{Pg} \mathrm{C}$ sink in the 1990s (Fig. 3c). Furthermore, it is estimated that enhanced remineralization of sinking organic carbon in STMW (Lomas et al., 2010) may have contributed $0.109 \pm 0.019 \mathrm{Pg} \mathrm{C}$ or $14 \pm 2 \%$ to the total sink. The remainder (i.e. $0.262 \mathrm{Pg} \mathrm{C}$ or $34 \%$ of the total sink) must be due to changes in DIC contents during formation of the STMW at the outcrop due to a combination of changes in air-sea gas exchange rates and water mass contributions to STMW. With movement northward of the Gulf Stream and STMW outcrop during an NAO positive period, entrainment of high DIC from deeper water (as shown in DIC sections across the STMW outcrop, Marshall et al., 2009; Andersson et al., 2012) and less mixing with relatively low DIC subtropical gyre waters during winter STMW formation potentially contribute to higher DIC input into the STMW (Fig. 5e).

In the 2000s, the observed uptake was much reduced compared to the 1990s at $0.159 \mathrm{PgC}$ (Fig. 5f). Indeed, this is much less than predicted from equilibration with anthropogenic $\mathrm{CO}_{2}$ in the atmosphere (i.e. $0.301 \pm 0.030 \mathrm{PgC}$ ). Furthermore, an additional $0.082 \pm 0.014 \mathrm{Pg} \mathrm{C}$ may have accumulated in STMW during this period due to enhanced remineralization of organic carbon in STMW. These two terms have to be balanced by reduced input of DIC to the STMW during winter formation of STMW (here computed at -0.025 Pg C; Fig. 5f) and loss from STMW due to mixing with surface waters/seasonal thermocline and/or enhanced diapycnal mixing with waters deeper than STMW. Given that the winter DIC ${ }^{\text {surface }}$ increases by $0.70 \mu \mathrm{mol} \mathrm{kg}^{-1} \mathrm{yr}^{-1}$, we estimate that STMW may have lost 0.198 Pg C (Fig. 5f) due to mixing with surface waters. The implication is that much of the anthropogenic $\mathrm{CO}_{2}$ uptake into STMW during the 2000s will have been lost to surface waters (in contact with the atmosphere) and thus ventilated over a shorter timeframe. Thus, in contrast to the 1990s, the STMW appears not to have been a sink for anthropogenic $\mathrm{CO}_{2}$ in the 2000s. Indeed, without the potential increase in DIC ${ }^{\text {STMW }}$ due to enhanced remineralization of organic carbon, the DIC content of STMW would have declined during the 2000s.
The observations at BATS thus indicate that the phase of the NAO is important for determining the long-term and short-term sinks of $\mathrm{CO}_{2}$ into STMW. During NAO positive phases, the $\mathrm{CO}_{2}$ sink into STMW appears to be long-term (i.e. more than $10 \mathrm{yr}$ ), whilst it is short-term (i.e. less than $10 \mathrm{yr}$ ) during the NAO neutral/negative period of the 2000s. As such, the reduced potential for uptake and long-term storage of $\mathrm{CO}_{2}$ in STMW during the 2000s likely contributed to the observed decline in the North Atlantic Ocean $\mathrm{CO}_{2}$ sink during this decade (Schuster and Watson, 2007; Watson et al., 2009). It may be that the 1990s uptake and storage of $\mathrm{CO}_{2}$ into the STMW reflects an anomalous decade since the winter NAO was predominantly neutral/negative from the 1950 s to 1980 s, with a return to this state in the 2000s. This study supports the findings of other studies (Gruber et al., 2002; Bates et al., 2002; McKinley et al., 2004; Thomas et al., 2008; Gruber, 2009; Ullman et al., 2009; McKinley et al., 2011) that natural climate variability such as NAO imparts a significant influence on $\mathrm{CO}_{2}$ sinks in the North Atlantic Ocean.

\section{Conclusions}

The observations at BATS thus indicate that the phase of the NAO is important for determining the long-term and shortterm sinks of $\mathrm{CO}_{2}$ into STMW. During NAO positive phases, the $\mathrm{CO}_{2}$ sink into STMW appears to be long-term (i.e. more than $10 \mathrm{yr}$ ), whilst it is short-term (i.e. less than $10 \mathrm{yr}$ ) during the NAO neutral/negative period of the 2000s. As such, the reduced potential for uptake and long-term storage of $\mathrm{CO}_{2}$ in STMW during the 2000s likely contributed to the observed decline in the North Atlantic Ocean $\mathrm{CO}_{2}$ sink during this decade. It may be that the 1990s uptake and storage of $\mathrm{CO}_{2}$ into the STMW reflects an anomalous decade since the winter NAO was predominantly neutral/negative from the 1950 s to 1980 s, with a return to this state in the 2000s. Thus, the NAO imparts a significant influence on $\mathrm{CO}_{2}$ sinks in the North Atlantic Ocean.

Acknowledgements. The author wishes to express his deep appreciation to many following individuals: Andreas J. Andersson and Andrew J. Peters for discussion, Anthony H. Knap (principal investigator) and other present and past BATS investigators, Rodney J. Johnson, Anthony F. Michaels, Dennis A. Hansell, Deborah K. Steinberg, Craig A. Carlson and Michael W. Lomas. Past and present analysts for seawater carbonate chemistry at BIOS for the BATS project, include Frances A. Howse, Margaret Best, Julian Mitchell, Brett Purinton, Keven Neely and Rebecca Garley, with data QC/QA by Christine Pequignet and Marlene Jeffries. Many BIOS scientists and technicians have spent dedicated time at sea sampling at BATS and Hydrostation S, including: Timothy J. Jickells, Rachel Dow, Kandace Binkley, Ann Close, Kjell Gundersen, Jens Sorensen, Elizabeth Caporelli, Fred Bahr, Steven J. Bell, Patrick Hyder, Vivienne Lochhead, Paul Lethaby, Marta Sanderson, Megan Roadman, Debra A. Lomas, Mary-Margaret 
Murphy, Sybille Pluvinage, Lilia M. Jackman, Matthew A. Tiahlo, Jonathan D. Whitefield, Kevin Lew, Dafydd (Gwyn) Evans, Elyse van Meersche, James Sadler, Matthew Wilkinson, and Sam Monk. The captains and crews of the R/V Weatherbird, R/V Weatherbird II and R/V Atlantic Explorer are also thanked. The National Science Foundation is thanked for its support of the BATS project.

Edited by: G. Herndl

\section{References}

Alfutis, M. A. and Cornillon, P.: Annual and interannual changes in the North Atlantic STMW layer properties, J. Phys. Oceanogr., 31, 2066-2086, 2001.

Andersson, A. J., Krug, L. A., Bates, N. R., and Doney, S.: Air-sea $\mathrm{CO}_{2}$ flux in the North Atlantic subtropical gyre: role and influence of STMW formation, Deep-Sea Res. II, in press, 2012.

Bates, N. R.: Interannual variability of oceanic $\mathrm{CO}_{2}$ and biogeochemical properties in the Western North Atlantic subtropical gyre, Deep-Sea Res. II, 48, 1507-1528, doi:10.1016/S09670645(00)00151-X, 2001.

Bates, N. R.: Interannual variability of the oceanic $\mathrm{CO}_{2}$ sink in the subtropical gyre of the North Atlantic Ocean over the last two decades, J. Geophys. Res. Ocean., 112, C09013, doi:10.1029/2006JC003759, 2007.

Bates, N. R. and Peters, A. J.: The contribution of atmospheric acid deposition to ocean acidification in the subtropical North Atlantic Ocean, Mar. Chem., 107, 547-558, doi:10.1016/j.marchem.2007.08.002, 2007.

Bates, N. R., Michaels, A. F., and Knap, A. H.: Seasonal and interannual variability of oceanic carbon dioxide species at the US JGOFS Bermuda Atlantic Time-series Study (BATS) site, DeepSea Res. II, 43, 347-383, doi:10.1016/0967-0645(95)00093-3, Corrigendum: 43, 1435-1435, 1996a.

Bates, N. R., Michaels, A. F., and Knap, A. H.: Alkalinity changes in the Sargasso Sea: Geochemical evidence of calcification?, Mar. Chem., 51, 347-358, doi:10.1016/0304-4203(95)00068-2, 1996b.

Bates, N. R., Pequignet, A. C., Johnson, R. J., and Gruber, N.: A short-term sink for atmospheric $\mathrm{CO}_{2}$ in subtropical mode water of the North Atlantic Ocean, Nature, 420, 489-493, doi:10.1038/nature01253, 2002.

Bates, N. R., Best, M. H. P., Neely, K., Garley, R., Dickson, A. G., and Johnson, R. J.: Detecting anthropogenic carbon dioxide uptake and ocean acidification in the North Atlantic Ocean, Biogeosciences Discuss., 9, 989-1019, doi:10.5194/bgd-9-9892012, 2012.

Behringer, D. and Stommel, H.: The Beta-Spiral in the North Atlantic subtropical gyre, Deep-Sea Res., 27, 225-238, 1980.

Dickson, A. G.: Thermodynamics of the dissociation of boric acid in synthetic seawater from 273.15 to 318.15 K, Deep Sea Res. Part A, 37, 755-766, 1990.

Dickson, A. G. and Millero, F. J.: A Comparison of the Equilibrium Constants for the dissociation of carbonic acid in seawater media, Deep Sea Res. Part A, 34, 1733-1743, 1987.

Dickson, A. G., Sabine, C. L., and Christian, J. R.: Guide to best practices for ocean $\mathrm{CO}_{2}$ measurements, Sidney, British Columbia, North Pacific Marine Science Organization, PICES Special Publication 3, 2007.
Dore, J. E., Lukas, R., Sadler, D. W., Church, M. J., and Karl, D. M.: Physical and biogeochemical modulation of ocean acidification in the central North Pacific, Proc. Nat. Aca. Sci., 106, 1223512240, doi:10.1073/pnas.0906044106, 2009.

Forget, G., Maze, G., Buckley, M., and Marshall, J.: Estimated Seasonal Cycle of North Atlantic Eighteen Degree Water, J. Phys. Ocean., 41, 269-286, doi:10.101175/2010JPO4257.1, 2011.

González-Dávila, M., Santana-Casiano, J. M., Rueda, M. J., and Llinás, O.: The water column distribution of carbonate system variables at the ESTOC site from 1995 to 2004, Biogeosciences, 7, 3067-3081, doi:10.5194/bg-7-3067-2010, 2010.

Gruber, N.: Carbon cycle: Fickle trends in the ocean, Nature, 458, 155-156, 2009.

Gruber, N., Bates, N. R., and Keeling, C. D.: Interannual variability in the North Atlantic Ocean carbon sink, Science, 298, 2374 2378, doi:10.1126/science.1077077, 2002.

Hanawa, H. and Talley, L.: Mode waters, Ocean Circulation and Climate, edited by: Siedler, J., Church, J., and Gould, J., Editors, Academic Press, 373-386, 2001.

Hurrell, J. W.: Decadal trends in the North-Atlantic OscillationRegional temperatures and precipitation, Science, 269, 676-679, 1995.

Hurrell, J. W. and Deser, C.: North Atlantic climate variability: The role of the North Atlantic, J. Mar. Syst., 79, 231-244, doi:10.1016/j.jmarsys.2009.11.002, 2009.

Hurrell, J. W., Kushnir, Y., and Visbeck, M.: Climate-The North Atlantic oscillation, Science, 291, 603-605, 2001.

Jenkins, W. G.: On the climate of the subtropical gyre: Decade timescale variation in water mass renewal in the Sargasso Sea, J. Mar. Res., 40, 265-290, 1982.

Joyce, T. M., Deser, C., and Spall, M. A.: The relation between decadal variability of subtropical mode water and the North Atlantic Oscillation, J. Climate, 13, 2550-2569, 2000.

Kwon, Y. and Riser, S.: North Atlantic subtropical mode water: A history of ocean-atmosphere interaction 1961-2000, Geophys. Res. Lett., 31, L19307, doi:10.1029/2004GL021116, 2004.

Levine, N. M., Doney, S. C., Lima, I., Wanninkhof, R., Sabine, C. L., Feely, R. A., and Bates, N. R.: The impact of interannual variability on the uptake and accumulation of anthropogenic $\mathrm{CO}_{2}$ in the North Atlantic, Global Biogeochem. Cy., 25, GB3022, doi:10.1029/2010GB003892, 2011.

Lomas, M. W., Steinberg, D. K., Dickey, T., Carlson, C. A., Nelson, N. B., Condon, R. H., and Bates, N. R.: Increased ocean carbon export in the Sargasso Sea linked to climate variability is countered by its enhanced mesopelagic attenuation, Biogeosciences, 7, 57-70, doi:10.5194/bg-7-57-2010, 2010.

Marshall, J., Kushnir, Y., Chang, P., Czaja, A., Dickson, R., Hurrell, J., McCartney, M., Saravanan, R., and Visbeck, M.: North Atlantic climate variability: Phenomena, impacts and mechanisms, Int. J. Climatol., 21, 1863-1898, 2001.

Marshall, J., Andersson, A., Bates, N., Dewar, W., Doney, S., Edson, J., Ferrari, R., Fratantoni, D., Gregg, M., Joyce, T., Kelly, K., Lozier, S., Lumpkin, R., Samuelson, R., Skyllingstad, E., Straneo, F., Talley, L., Toole, J., and Weller, R.: Observing the cycle of convection and restratification over the Gulf Stream system and the subtropical gyre of the North Atlantic Ocean: preliminary results from the CLIMODE field campaign, B. Am. Meteorol. Soc., 90, 1337-1350, doi:10.1175/2009BAMS2706.1, 2009. 
Maze, G., Forget, G., Buckley, M., Marshall, J., and Cerovecki, I.: Using transformation and formation maps to study the role of air-sea heat fluxes in North Atlantic Eighteen Degree Water formation, J. Phys. Oceanogr., 39, 1818-1835, 2009.

McKinley, G. A., Follows, M. J., and Marshall, J.: Mechanisms of air-sea $\mathrm{CO}_{2}$ flux variability in the equatorial Pacific and the North Atlantic, Global Biogeochem. Cy., 18, GB2011, doi:10.1029/2003GB002179, 2004.

McKinley, G. A., Fay, A. R., Takahashi, T., and Metzl, N.: Convergence of atmospheric and North Atlantic carbon dioxide trends on multidecadal timescales, Nat. Geosci., 4, 606-610, doi:10.1038/ngeo1193, 2011.

Mehrbach, C., Culberson, C. H., Hawley, J. E., and Pytkowicz, R. M.: Measurement of the apparent dissociation constants of carbonic acid in seawater at atmospheric pressure, Limnol. Oceanogr., 18, 897-907, 1973.

Metzl, N., Corbiere, A., Reverdin, G., Lenton, A., Takahashi, T., Olsen, A., Johannessen, T.. Pierrot, D., Wanninkhof, R., Olafsdottir, S. R., Solveig, R., Olafsson, J., and Ramonet, M.: Recent acceleration of the sea surface $\mathrm{fCO}_{2}$ growth rate in the North Atlantic subpolar gyre (1993-2008) revealed by winter observations, Global Biogeochem. Cy., 24, GB4004, doi:10.1029/2009GB003658, 2010.

Robbins, L. L., Hansen, M. E., Kleypas, J. A., and Meylan, S. C.: CO2calc: a user-friendly seawater carbon calculator for Windows, Max OS X, and iOS (iPhone), US Geological Survey Open-File Report, 2010-1280, 1-17, available at: http://pubs. usgs.gov/of/2010/1280/ (last access: 6 December 2011), 2010.

Schuster, U. and Watson, A. J.: A variable and decreasing sink for atmospheric $\mathrm{CO}_{2}$ in the North Atlantic, J. Geophys. Res.-Ocean., 112, C11006, doi:10.1029/2006JC003941, 2007.

Spall, M. A.: Cooling spirals and recirculation in the subtropical gyre, J. Phys. Oceanogr., 22, 564-571, 1992.

Speer, K. and Tziperman, E.: Rates of water mass formation in the North Atlantic Ocean, J. Phys. Oceanogr., 22, 93-104, 1992.

Takahashi, T., Sutherland, S.C., Sweeney, C., Poisson, A., Metzl, N., Tilbrook, B., Bates, N., Wanninkhof, R., Feely, R. A., Sabine, C., Olafsson, J., and Nojiri, Y.: Global sea-air $\mathrm{CO}_{2}$ flux based on climatological surface ocean $\mathrm{pCO}_{2}$, and seasonal biological and temperature effects, Deep-Sea Res. II, 49, 1601-1622, doi:10.1016/S0967-0645(02)00003-6, 2002.
Takahashi, T., Sutherland, S.C., Wanninkhof, R., Sweeney, C., Feely, R. A., Chipman, D. W., Hales, B., Friederich, G., Chavez, F., Watson, A., Bakker, D. C. E., Schuster, U., Metzl, N., Yoshikawa-Inoue, H., Ishii, M., Midorikawa, Nojiri, Y., Kortzinger, A., Steinhoff, T., Hoppema, M., Olafsson, J., Arnarson, T. S., Tilbrook, B., Johannessen, T., Olsen, A., Bellerby, R., Wong, C. S., Delille, B., Bates, N. R., and de Baar, H. J. W.: Climatological mean and decadal change in surface ocean $p \mathrm{CO}_{2}$, and net sea-air $\mathrm{CO}_{2}$ flux over the global oceans, Deep-Sea Res. II, 56, 554-577, doi:10.1016/j.dsr2.2008.12.009, 2009.

Thomas, H., Prowse, A. E. F., van Heuven, S., Bozec, Y., de Baar, H. J. W., Schiettecatte, L.S., Suykens, K., Kone, M., Borges, A. V., Lima, I. D., and Doney, S. C.: Rapid decline of the $\mathrm{CO}_{2}$ buffering capacity in the North Sea and implications for the North Atlantic Ocean, Global Biogeochem. Cy., 21, GB4001, doi:10.1029/2006GB002825, 2007.

Thomas, H., Prowse, A. E. F., Lima, I. D., Doney, S. C., Wanninkhof, R., Greatbach, R. J., Schuster, U., and Corbiere, A.: Changes in the North Atlantic Oscillation influence $\mathrm{CO}_{2}$ uptake in the North Atlantic over the past 2 decades, Global Biogeochem. Cy., 22, GB4027, doi:10.1029/2007GB003167, 2008.

Ullman, D. J., McKinley, G. A., Bennington, V., and Dutkiewicz, S.: Trends in the North Atlantic carbon sink: 1992-2006, Global Biogeochem. Cy., 23, GB4011, doi:10.1029/2008GB003383, 2009.

Watson, A.J., Schuster, U., Bakker, D. C. E., Bates, N. R., Corbiere, A., Gonzalez-Davila, M., Friedrich, T., Hauck, J., Heinze, C., Johannessen, T., Körtzinger, A., Metzl, N., Olafsson, J., Olsen, A., Oschlies, A., Padin, X. A., Pfiel, B., Santana-Casiano, M., Steinhoff, T., Telszewski, M., Rios, A. F., Wallace, D. W. R., and Wanninkhof, R.: Accurately tracking the variation in the North Atlantic sink for atmospheric $\mathrm{CO}_{2}$, Science, 326, 1391-1393, doi:10.1126/science.1177394, 2009.

Worthington, L. V.: The $18^{\circ}$ water in the Sargasso Sea, Deep-Sea Res., 5, 297-305, 1959.

Worthington, L. V.: On the North Atlantic Circulation, Johns Hopkins University Press, 110 pp., 1976. 